\title{
PENGARUH PEMBERIAN K-KARAGENAN DAN í-KARAGENAN TERHADAP PENURUNAN KADAR GLUKOSA DARAH TIKUS HIPERGLIKEMIA
}

\author{
Thamrin Wikanta*), Rahma Damayanti*), dan Lestari Rahayu**)
}

\begin{abstract}
ABSTRAK
Penelitian tentang pengaruh pemberian $\kappa$-karagenan dan i-karagenan terhadap penurunan kadar glukosa darah tikus yang mengalami kerusakan pankreas akibat induksi aloksan monohidrat telah dilaksanakan. Dibuat 6 kelompok perlakuan hewan percobaan, masing-masing kelompok terdiri dari 5 ekor. Kelompok I kontrol normal (tanpa perlakuan), kelompok II (kontrol negatif) diberikan air suling ( $1 \mathrm{~mL} / 200 \mathrm{~g}$ bobot badan), kelompok III (kontrol positif) diberikan injeksi insulin $(0,756 \mathrm{UI} / 200 \mathrm{~g}$ bobot badan), kelompok IV (kontrol positif) diberikan suspensi klorpropamida $(2,52 \mathrm{mg} / 200 \mathrm{~g}$ bobot badan), kelompok $V$ diberikan $\kappa$-karagenan $(0,01 \mathrm{~g} / 200 \mathrm{~g}$ bobot badan), kelompok VI diberikan í-karagenan (0,01 g/200 g bobot badan). Kelompok I, II, IV, V, dan VI, diberikan secara oral, sedangkan kelompok III diberikan secara subkutan. Hasil riset menunjukkan bahwa к-karagenan dan i-karagenan dapat menurunkan kadar glukosa darah selama 15 hari pemberian pada tikus diabetes. Pemberian $\kappa$-karagenan dosis 0,01 g/200 g bobot badan dapat menurunkan kadar glukosa darah sebesar 37,55\% dan pemberian í-karagenan dosis $0,01 \mathrm{~g} / 200 \mathrm{~g}$ bobot badan dapat menurunkan kadar glukosa darah sebesar $42,87 \%$.
\end{abstract}

\section{ABSTRACT: Effect of $\kappa$-carrageenan and $i$-carrageenan feeding on the reduction of hyperglicemic rat blood glucose level. By: Thamrin Wikanta, Rahma Damayanti and Lestari Rahayu}

Research on the effect of $\kappa$-carrageenan and $i$-carrageenan feeding on the reduction of rat blood glucose level in which its pancreas was previously damaged by aloxan monohydrate induction has been carried out. There were 6 groups of rat, each group containing 5 rats. Group $I$ (normal control) was untreated, group II (negative control) was treated with distilled water (1 mL/ $200 \mathrm{~g}$ of body weight), group III (positive control) was treated with insulin injection (0.756 IU/200 $g$ of body weight), group IV (positive control) was treated with chlorpropamide suspension $(2.52$ $\mathrm{mg} / 200 \mathrm{~g}$ of body weight), group $V$ was treated with $\kappa$-carrageenan $(0.01 \mathrm{~g} / 200 \mathrm{~g}$ of body weight), group VI was treated with $i$-carrageenan $(0.01 \mathrm{~g} / 200 \mathrm{~g}$ of body weight). Group I, II, IV, V, and VI, were treated orally, while group III was treated by subcutan injection. The result revealed that $\kappa$ carrageenan and $i$-carrageenan were able to reduce the blood glucose level during 15 days feeding to the diabetic rats. Feeding of $\kappa$-carrageenan with the dose of $0.01 \mathrm{~g} / 200 \mathrm{~g}$ of body weight was able to reduce $37.55 \%$ of the blood glucose level, while feeding of $i$-carrageenan with the dose of $0.01 \mathrm{~g} / 200 \mathrm{~g}$ of body weight was able to reduce $42.87 \%$ of the blood glucose level.

\section{KEYWORDS: $\quad \kappa$-carrageenan, i-carrageenan, rat blood glucose level}

\section{PENDAHULUAN}

Dalam simposium "Pencegahan Diabetes Mellitus (DM) dalam Pelayanan Kesehatan Primer" pada 21 Agustus 2000 di Jakarta, dikemukakan oleh Jerzy Leowski bahwa berdasarkan data yang diperoleh Organisasi Kesehatan Dunia (WHO) tahun 1998, Indonesia menduduki peringkat ke-6 dalam jumlah penderita diabetes mellitus, setelah India, Cina, Rusia, Jepang, dan Brasil. Penderita pada 1995 sekitar 5 juta orang, dan pada tahun 2025 diperkirakan akan meningkat menjadi 12 juta orang. Hal ini terjadi akibat perubahan pola makan dan gaya hidup masyarakat urban yang dipengaruhi oleh lingkungannya (Anon., 2000).
Masyarakat yang hidup di sekitar pantai telah lama mengenal dan memanfaatkan rumput laut dalam kehidupan sehari-hari untuk makanan, sayuran, dan pengobatan secara tradisional. Beberapa jenis rumput laut penghasil agar, seperti: Gracilaria sp., Gelidium $\mathrm{sp}$. dan penghasil karagenan, seperti: Eucheuma sp. telah lama dikenal dan dimanfaatkan masyarakat untuk berbagai keperluan (Atmaja, 2000). Senyawa karagenan, hasil ekstraksi dari rumput laut jenis Eucheuma, adalah suatu fikokoloid yang merupakan senyawa polisakarida serat makanan (Sugiarto, 1987). Serat makanan ini mengandung gugusan ester sulfat dan 3,6-anhidrogalaktosa, dapat membentuk gel yang reversibel dengan titik gel pada suhu sekitar $35^{\circ} \mathrm{C}$.

\footnotetext{
") Peneliti pada Balai Besar Riset Pengolahan Produk dan Bioteknologi Kelautan dan Perikanan, DKP

*) Fakultas Farmasi - Universitas Pancasila, Jakarta
} 
Rumput laut jenis Eucheuma yang terdapat di Indonesia dan banyak dikonsumsi masyarakat adalah jenis $E$. cottonii penghasil kappa-karagenan dan $E$. spinosum penghasil iota-karagenan. Kedua senyawa karagenan tersebut sedikit berbeda dalam struktur kimia, kandungan sulfat serta kandungan 3,6anhidrogalaktosanya sehingga memberikan sifat fisikokimia yang berbeda (Suryaningrum et al., 1991).

Selama ini, serat makanan terutama yang larut air, misalnya alginat hasil ekstraksi dari rumput laut coklat jenis Sargassum sp. berguna bagi penderita penyakit diabetes mellitus (Wikanta et al., 2000; Wikanta et al., 2002). Sedangkan manfaat ikaragenan dan k-karagenan telah terbukti bermanfaat bagi penurunan kadar gula darah pada kelinci (Wikanta, 2005). Serat makanan, selain dapat memperlambat penyerapan glukosa dari larutan pada saluran cerna ke dalam aliran darah juga mempengaruhi penyerapan lemak (Wikanta et al., 2003). Telah diketahui bahwa polisakarida dinding sel tanaman dan lignin tidak dapat dicerna oleh enzim pencernaan mamalia, termasuk manusia, sehingga keuntungan mengkonsumsi makanan berserat terutama yang larut air, diantaranya dapat mengurangi atau menghambat laju kenaikan kadar glukosa darah secara mendadak (Mayer, 1995; Dalimartha, 2002).

Riset ini dilakukan untuk mengetahui efek hipoglikemik dari serat makanan к-karagenan (ekstrak dari Eucheuma cottonii) dan í-karagenan (ekstrak dari Eucheuma spinosum) secara in vivo menggunakan hewan percobaan tikus putih dan membandingkannya terhadap efek obat anti-diabetes parenteral (insulin) dan obat anti-diabetes oral (klorpropamida).

\section{BAHAN DAN METODE}

\section{Bahan}

Rumput laut yang digunakan sebagai bahan ekstraksi karagenan adalah hasil panen dari perairan selatan Pulau Bali pada tahun 2002. Sediaan uji yang diteliti adalah $\kappa$-karagenan hasil ekstraksi dari rumput laut merah jenis Eucheuma cottonii dan í-karagenan hasil ekstraksi dari rumput laut merah jenis Eucheuma spinosum.

\section{Hewan percobaan}

Hewan percobaan yang digunakan adalah 30 ekor tikus putih (Rattus norvegicus) galur Wistar, jenis kelamin jantan, bobot badan antara 200-250 gram, umur 3-3,5 bulan, yang diperoleh dari Bagian Perhewanan, Pusat Pengawasan Obat dan Makanan (PPOM), Jakarta.

\section{Perhitungan dosis}

Orientasi dosis untuk sediaan $\kappa$-karagenan dan i-karagenan diperoleh berdasarkan konversi perhitungan dari dosis lazim untuk pengobatan Ulcerative colitis pada manusia dengan bobot badan 70 kg (Reynolds, 1982).

\section{Perhitungan dosis obat insulin}

Dosis untuk manusia dewasa dengan bobot badan $50 \mathrm{~kg}$ adalah $30 \mathrm{Unit} / \mathrm{hari}$, jadi untuk bobot badan 70 $\mathrm{kg}$ menjadi $70 / 50 \times 30$ Unit/hari $=42$ Unit/hari. Dosis untuk tikus, dikalikan faktor konversinya 0,018 , menjadi: 42 Unit x 0,018 $=0,756$ Unit/hari/200 g bobot badan tikus.

\section{Perhitungan dosis obat klorpropamida}

Dosis untuk manusia dewasa dengan bobot badan $50 \mathrm{~kg}$ adalah $100 \mathrm{mg} / \mathrm{hari}$, jadi untuk bobot badan 70 $\mathrm{kg}$ menjadi $70 / 50 \times 100 \mathrm{mg} / \mathrm{hari}=140 \mathrm{mg} /$ hari. Dosis untuk tikus, dikalikan faktor konversinya yaitu 0,018 , menjadi: $140 \mathrm{mg}$ x 0,018 =2,52 mg/hari $/ 200 \mathrm{~g}$ bobot badan tikus.

\section{Perhitungan dosis karagenan}

Dosis lazim dan dianggap aman untuk pengobatan tukak saluran cerna (ulcerative colitis) pada manusia dewasa dengan bobot badan $70 \mathrm{~kg}$ adalah $10 \mathrm{~g} / \mathrm{hari}$ (Reynolds, 1982). Berdasarkan hasil orientasi, dosis karagenan yang efektif untuk menurunkan kadar glukosa darah tikus adalah $=0,01 \mathrm{~g} / 200 \mathrm{~g}$ bobot badan tikus. Dosis $\kappa$-karagenan atau í-karagenan $=0,01 \mathrm{~g} /$ $200 \mathrm{~g}$ bobot badan tikus. Volume yang diberikan pada hewan percobaan adalah $1 \mathrm{~mL} / 200 \mathrm{~g}$ bobot badan tikus, maka kadar larutan sediaan uji yang dibuat adalah $(0,01 \mathrm{~g} / 1 \mathrm{~mL})=1 \mathrm{~g} / 100 \mathrm{~mL}=1 \%$ larutan.

\section{Metode}

Uji efek anti-diabetes pada hewan percobaan menggunakan metode uji diabetes aloksan. Sediaan uji yang digunakan adalah $\kappa$-karagenan dan í-karagenan dengan dosis $0,01 \mathrm{~g} / 200 \mathrm{~g}$ bobot badan tikus. Sebagai pembanding (kontrol positif) adalah injeksi insulin dosis 0,756 Unit/hari/200 g bobot badan tikus dan klorpropamida dosis $2,52 \mathrm{mg} / \mathrm{hari} / 200 \mathrm{~g}$ bobot badan tikus, serta air suling $1 \mathrm{~mL} / 200 \mathrm{~g}$ bobot badan tikus (kontrol negatif). Pengukuran kadar glukosa darah hewan percobaan dengan metoda enzimatis (glukosa oksidase) menggunakan alat glukometer life scan. Pengamatan dilakukan selama jangka waktu 15 hari perlakuan. Pengambilan darah dilakukan sebelum dan sesudah pemberian perlakuan 
pada hari ke-0, 5, 10, dan 15. Data pengukuran kadar glukosa darah yang diperoleh diuji menggunakan statistik analisis varian satu arah, dilanjutkan dengan uji beda nyata terkecil (BNT).

\section{Prosedur Kerja}

Pelaksanaan pekerjaan dalam penelitian ini dilakukan sesuai dengan prosedur yang dikemukakan dalam Kelompok Kerja Ilmiah Phytomedica 1993 (KKI Phytomedica, 1993), sebagai berikut:

1). Sejumlah 30 ekor tikus dipelihara selama 1 minggu untuk penyesuaian lingkungan, mengontrol kesehatan, dan bobot badan, serta menyeragamkan makanan.

2). Masing-masing tikus ditimbang kemudian darahnya dicuplik melalui vena ekor tikus.

3). Semua tikus dibuat hiperglikemik dengan pemberian suntikan aloksan monohidrat secara intra vena dengan dosis $75 \mathrm{mg} / \mathrm{kg}$ bobot badan tikus, kemudian dipelihara selama satu minggu agar terjadi hiperglikemik.

4). Sebelum dilakukan pengambilan darah, semua tikus dipuasakan selama kurang lebih 18 jam. Pengambilan darah awal dilakukan melalui ekor dari masing-masing tikus sebelum diberikan sediaan uji dan diukur kadar glukosa darah awalnya.

5). Semua tikus dibagi menjadi 6 kelompok dan masing-masing kelompok diberi perlakuan sebagai berikut:

- Kelompok I (kontrol normal) tanpa perlakuan.

- Kelompok II (kontrol negatif) diberi air suling (1 $\mathrm{mL} / \mathrm{har} / 200 \mathrm{~g}$ bobot badan).

- Kelompok III (kontrol positif) diberi injeksi insulin (dosis 0,756 Unit/hari/200 g bobot badan).

- Kelompok IV (kontrol positif) diberi obat antidiabetes oral klorpropamida (dosis 2,52 mg/ hari/200 g bobot badan)

- Kelompok $V$ diberi $\kappa$-karagenan dosis 0,01 $\mathrm{g} / 200 \mathrm{~g}$ bobot badan $(1 \mathrm{~mL} /$ hari/200 $\mathrm{g}$ bobot badan)

- Kelompok VI diberi í-karagenan 0,01 g/200 g bobot badan ( $1 \mathrm{~mL} /$ hari $/ 200 \mathrm{~g}$ bobot badan).

6). Masing-masing tikus mendapat satu macam sediaan uji dengan dosis seperti di atas, yang diberikan secara oral. Sediaan obat insulin (kontrol positif) diberikan secara parenteral. Semua sediaan diberikan satu kali setiap hari selama 15 hari.

7). Setelah selesai pemberian sediaan uji, semua tikus diistirahatkan di dalam kandang masingmasing dan diberi makan dan minum ad libitum dengan makanan standar dalam bentuk pellet dan minuman air suling.
8). Sebelum dan setelah 2,5 jam pada pemberian sediaan uji, darah tikus dicuplik pada hari ke-0, 5,10 , dan 15 dari masing-masing kelompok.

9). Setelah percobaan selesai semua tikus dimatikan.

\section{Persentase Penurunan Kadar Glukosa Darah Tikus}

Untuk mengetahui besarnya kemampuan sediaan uji dalam menurunkan kadar glukosa darah tikus maka dilakukan perhitungan berdasarkan Luas Daerah di Bawah Kurva (LDDK) yang terbentuk oleh setiap perlakuan dan membandingkannya terhadap kontrol negatif (Ritschel, 1986) menggunakan rumus sebagai berikut:

$$
P=\frac{(\text { LDDK kn }- \text { LDDK pk) }}{\text { LDDK kn }} \times 100 \%
$$

Keterangan :

$$
\begin{aligned}
\mathrm{P}= & \text { persentase penurunan kadar glukosa } \\
& \text { darah } \\
\mathrm{kn}= & \text { kontrol negatif (air suling) } \\
\mathrm{pk}= & \text { perlakuan (injeksi insulin, } \\
& \text { klorpropamida, } \mathrm{k}-\mathrm{karagenan,} \mathrm{i-} \\
& \text { karagenan). }
\end{aligned}
$$

Adapun LDDK dihitung dengan kaidah trapesium dengan membuat kurva hubungan antara kadar glukosa darah dengan waktu.

\section{HASIL DAN BAHASAN}

\section{Rata-rata Bobot Badan Tikus Sebelum dan Sesudah Perlakuan}

Sebelum mulai percobaan semua tikus dari masing-masing kelompok ditimbang bobot badannya, kemudian dipelihara selama satu minggu. Sesudah diberi perlakuan sesuai dengan pembagian kelompok, pada hari ke-0 (hiperglikemia), 5, 10, dan 15 semua tikus ditimbang kembali. Hasil pengamatan dapat dilihat pada Gambar 1. Terlihat bahwa tikus hiperglikemia mengalami penurunan bobot badan. Salah satu gejala yang khas dari kelainan metabolisme, seperti pada diabetes adalah kehilangan bobot badan, padahal nafsu makan sangat baik. Keadaan ini adalah akibat dari glukosa tidak dapat dimetabolisme dengan cepat menjadi energi yang dibutuhkan tubuh sehingga terjadi depresi sel lemak dan protein untuk memenuhi kebutuhan energi tubuh tersebut (Tjokroprawiro, 1999; Widowati, 2003).

Setelah perlakuan pemberian sediaan uji selama 15 hari, bobot badan rata-rata tikus pada semua kelompok perlakuan mengalami peningkatan dibandingkan dengan keadaan hiperglikemia. 


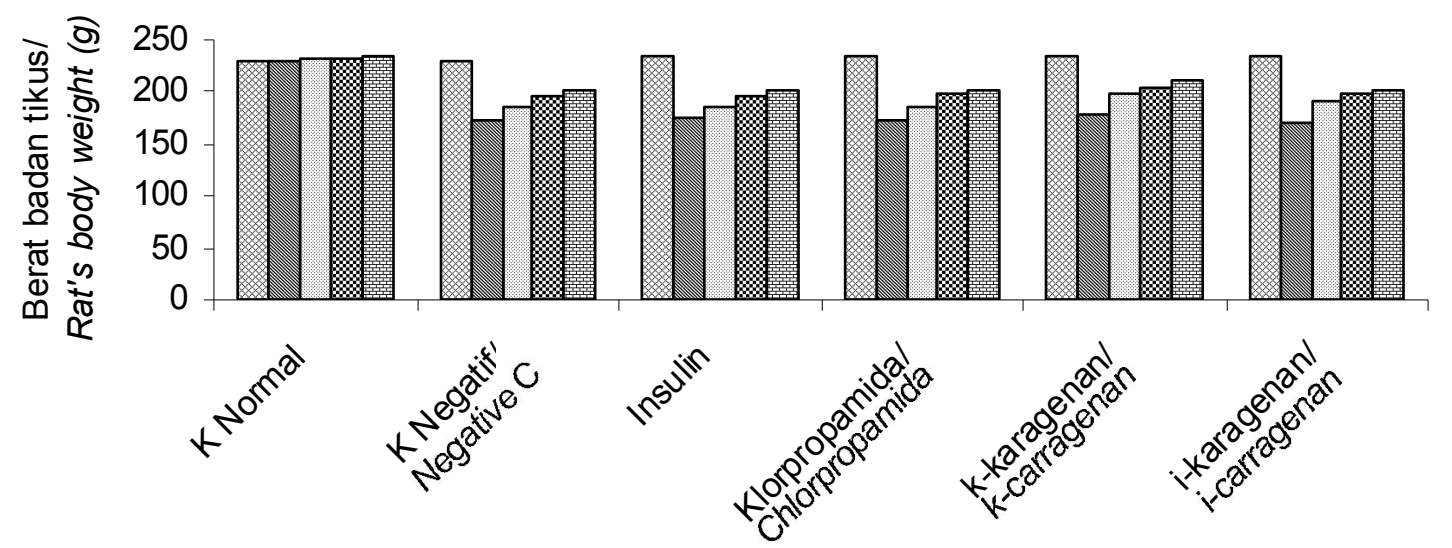

Kelompok perlakuan/Group of treatment

Berat awal/Initial weight

05 hari perlakuan/05 days treatment 15 hari perlakuan/15 days treatment

Hiperglikemik/Hyperglicemic

10 hari perlakuan/10 days treatment

Gambar 1. Rata-rata bobot badan tikus (gram) sebelum dan sesudah perlakuan dari setiap kelompok perlakuan selama pengamatan.

Figure 1. Mean of rat's body weight (gram) before and after treatment of each group during observation.

Kenaikan bobot badan pada kelompok kontrol negatif, injeksi insulin, perlakuan klorpropamida, $\kappa$-karagenan, dan í-karagenan berturut-turut adalah 28,$3 ; 27,4 ; 29,0$; 34,1 ; dan 30,1 gram.

\section{Analisis Kadar Glukosa Darah Tikus}

\section{Kadar glukosa darah tikus (mg/dL) sebelum dan sesudah perlakuan}

Pengamatan kadar glukosa darah tikus dilakukan pada selang waktu 5 hari, yang dimulai sejak keadaan awal (kondisi normal) saat tikus belum mendapat perlakuan, dilanjutkan pada saat sebelum dan sesudah pemberian sediaan uji, setelah tikus mengalami kondisi hiperglikemia karena injeksi aloksan, yaitu pada hari ke $0,5,10,15$. Data hasil pengamatan berdasarkan kelompok perlakuan dapat dilihat pada Gambar 2.

\section{Analisis Statistik Kadar Glukosa Darah Awal}

\section{Kondisi tikus normal (sebelum induksi aloksan)}

Uji keseragaman kondisi awal hewan percobaan sebelum diberi perlakuan dilakukan menggunakan data kadar glukosa darah awal dari masing-masing kelompok perlakuan, selanjutnya dianalisis secara statistik. Hasil pengukuran kadar glukosa darah dapat dilihat pada Gambar 3. Terlihat bahwa kadar glukosa darah tikus berkisar antara 75,8-76,6 mg/dL. Hasil analisis statistik menggunakan analisis varian satu arah menunjukkan bahwa kadar glukosa darah awal tikus tidak berbeda nyata antar hewan percobaan dalam setiap kelompok perlakuan, artinya kadar glukosa darah awal hewan percobaan yang digunakan kondisinya seragam.

\section{Kondisi tikus hiperglikemia (hari ke-0 setelah induksi aloksan)}

Untuk mengetahui kondisi awal hewan percobaan setelah penyuntikan aloksan tetapi sebelum diberi perlakuan sediaan uji dilakukan pengukuran kadar glukosa darah dari masing-masing kelompok perlakuan, selanjutnya data dianalisis secara statistik menggunakan analisis varian satu arah. Hasil pengukuran kadar glukosa darah dapat dilihat pada Gambar 3. Terlihat bahwa akibat injeksi aloksan secara intra vena dosis $75 \mathrm{mg} / \mathrm{kg}$ bobot badan tikus, setelah 1 minggu terjadi peningkatan kadar glukosa darah yang berkisar antara 287,4-291,8 mg/dL. Pada kelompok tikus tanpa induksi aloksan, kadar glukosa darah berkisar $77,2 \mathrm{mg} / \mathrm{dL}$. Hasil analisis statistik menunjukkan bahwa kadar glukosa darah berbeda nyata antar hewan percobaan dalam setiap kelompok sebagai akibat dari perlakuan yang diberikan. Selanjutnya dari hasil analisis beda nyata terkecil (BNT) tampak bahwa antara kontrol normal dengan kelompok perlakuan berbeda nyata. Kenaikan kadar glukosa darah ini dapat dikatakan sebagai keadaan hiperglikemia karena kadar glukosa darah puasa lebih tinggi dari $120 \mathrm{mg} / \mathrm{dL}$ (Tjokroprawiro, 1999). Kondisi ini dapat terjadi karena aloksan yang diberikan dapat merusak sel- $\beta$ pankreas tanpa merusak sel- $\alpha$. Dengan rusaknya sel- $\beta$ maka sekresi insulin menjadi 


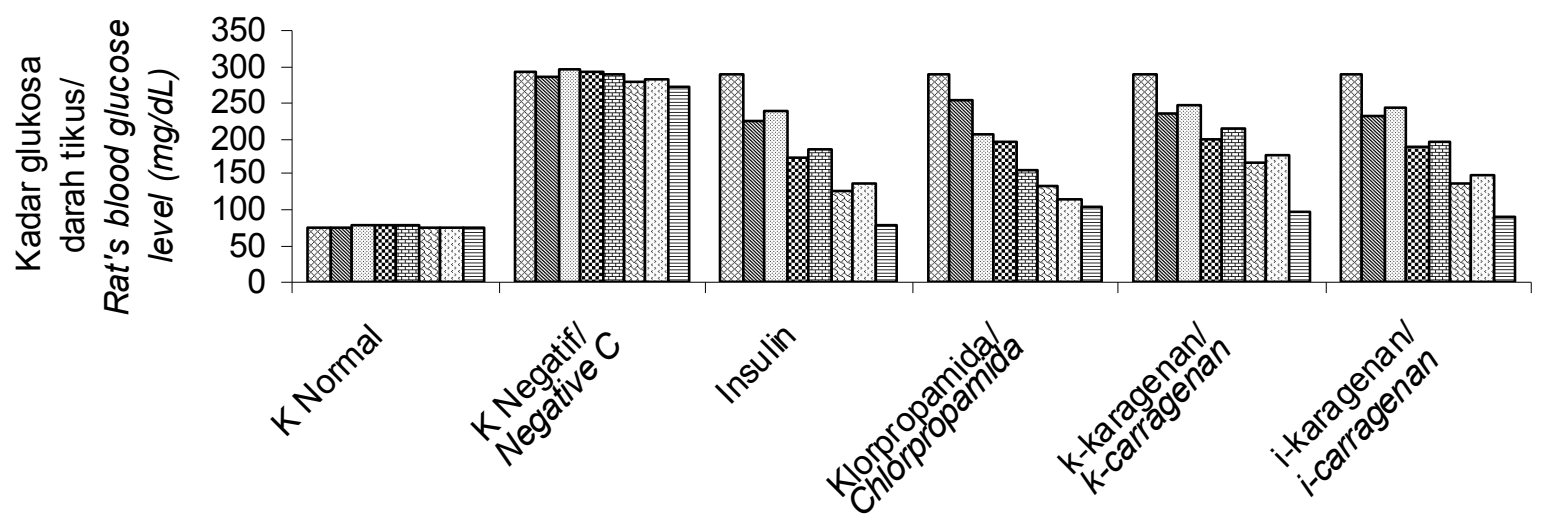

Kelompok perlakuan/Group of treatment

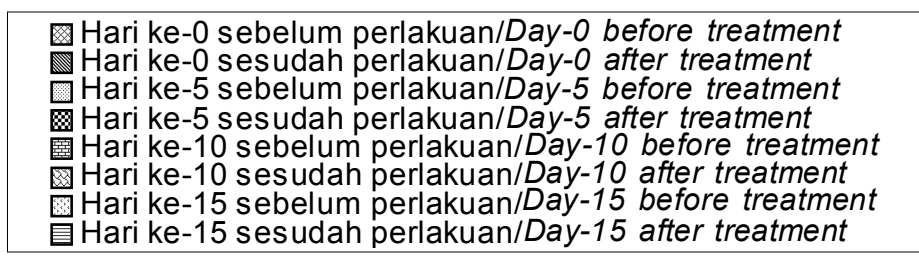

Gambar 2. Rata-rata kadar glukosa darah tikus ( $\mathrm{mg} / \mathrm{dL}$ ) sebelum dan sesudah perlakuan dari setiap kelompok perlakuan selama pengamatan.

Figure 2. Mean of rat's blood glucose level $(\mathrm{mg} / \mathrm{dL})$ before and after treatment of each group during observation.

berkurang, sementara itu sekresi glukagon oleh sel- $\alpha$ tetap berlangsung sehingga mengakibatkan regulasi insulin-glukagon terganggu yang mengakibatkan meningkatnya kadar glukosa dalam darah (Katzung, 1989).

\section{Analisis statistik kadar glukosa darah akhir (2,5 jam sesudah 15 hari perlakuan)}

Untuk melihat perbedaan kadar glukosa darah akhir (2,5 jam sesudah pemberian sediaan uji pada hari

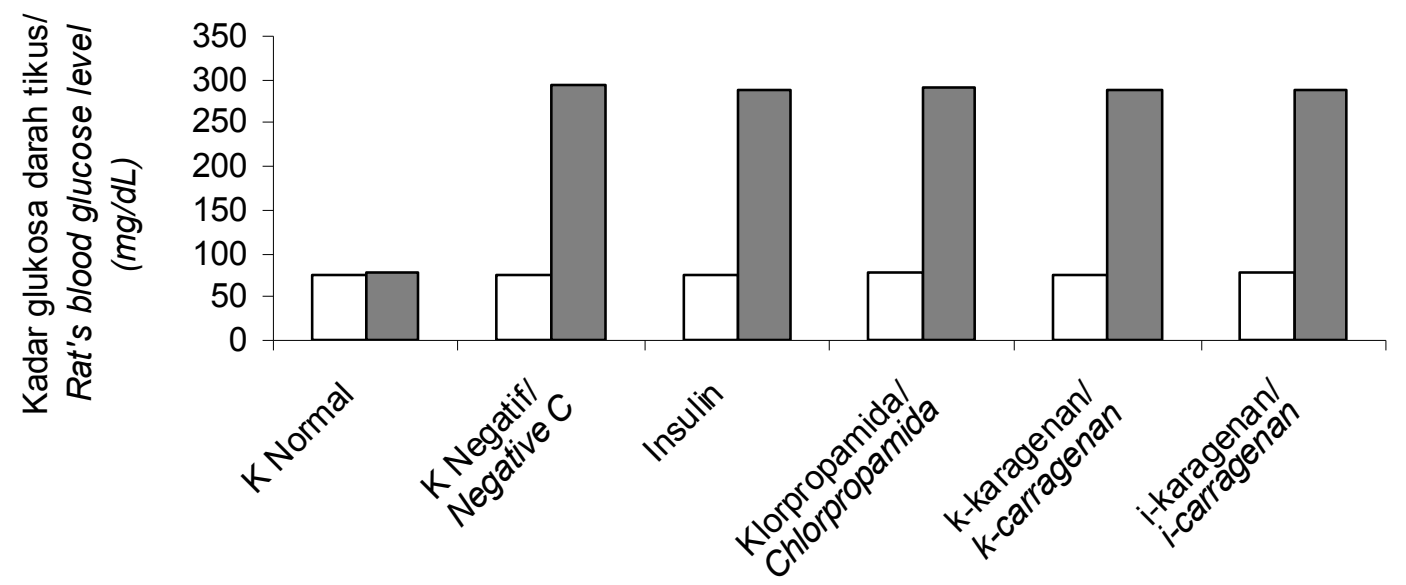

Kelompok perlakuan/Group of treatment

$\square$ Sebelum injeksi aloksan/Before aloxan injection

$\square$ Setelah injeksi aloksan/After aloxan injection

Gambar 3. Kadar glukosa darah awal tikus ( $\mathrm{mg} / \mathrm{dL}$ ) dari tiap kelompok sebelum perlakuan dan pada kondisi hiperglikemia sesudah injeksi aloksan pada hari ke-0.

Figure 3. Initial rat's blood glucose level ( $\mathrm{mg} / \mathrm{dL})$ from each group before treatment and at hyperglycemia condition after aloxan injection on day-0. 
ke-15) antar masing-masing kelompok maka dilakukan analisis statistik terhadap data yang didapatkan seperti terlihat pada Gambar 4. Hasil analisis anova menunjukkan ada perbedaan nyata maka analisis dilanjutkan dengan uji beda nyata terkecil (BNT).

Hasil analisis kadar glukosa darah menunjukkan bahwa antara kelompok kontrol negatif dengan kelompok injeksi insulin, klorpropamida, k-karagenan, i-karagenan terdapat perbedaan yang nyata, di mana tikus hiperglikemia yang diberi perlakuan tersebut kadar glukosanya turun dengan perbedaan yang sangat nyata bila dibandingkan dengan kontrol negatif. Tampak bahwa pemberian insulin, klorpropamida, k-karagenan, dan i-karagenan dapat menurunkan kadar glukosa darah hewan percobaan.

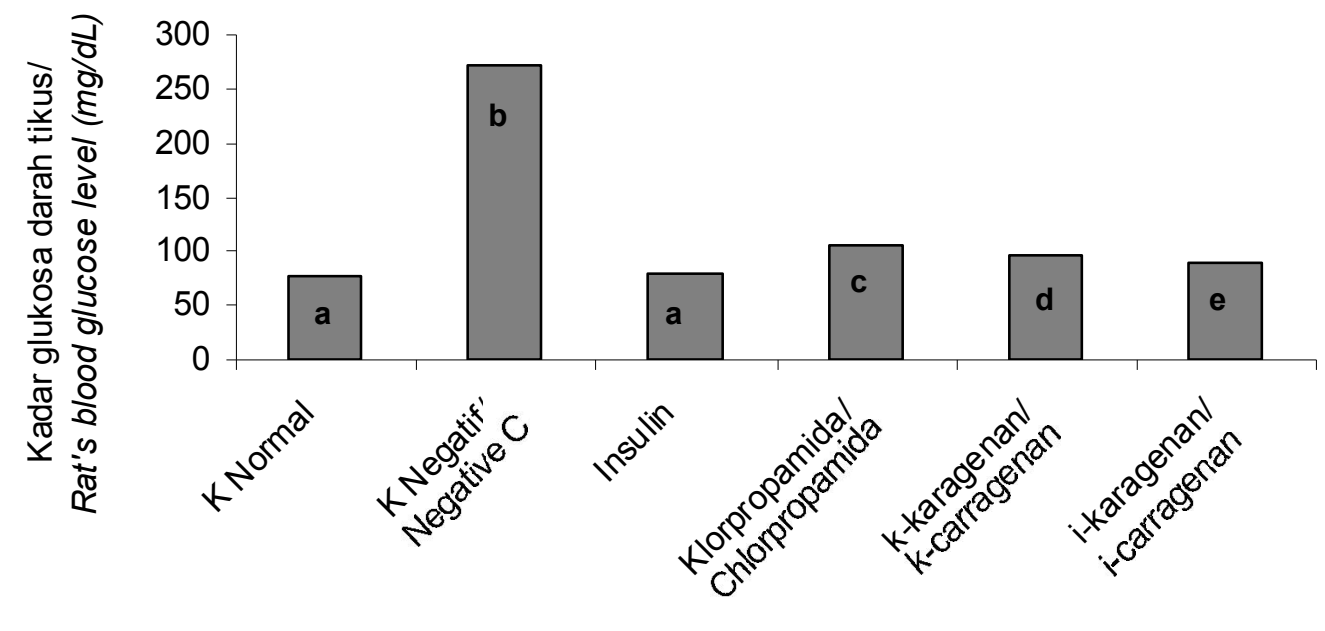

Kelompok perlakuan/Group of treatment

Keterangan/Note: berbeda notasi berarti berbeda nyata/different notation means significantly different

Gambar 4. Kadar glukosa darah tikus (mg/dL) pada 2,5 jam sesudah perlakuan hari ke-15.

Figure 4. Level of rat's blood glucose $(\mathrm{mg} / \mathrm{dL})$ at 2.5 hours after treatment on day 15.

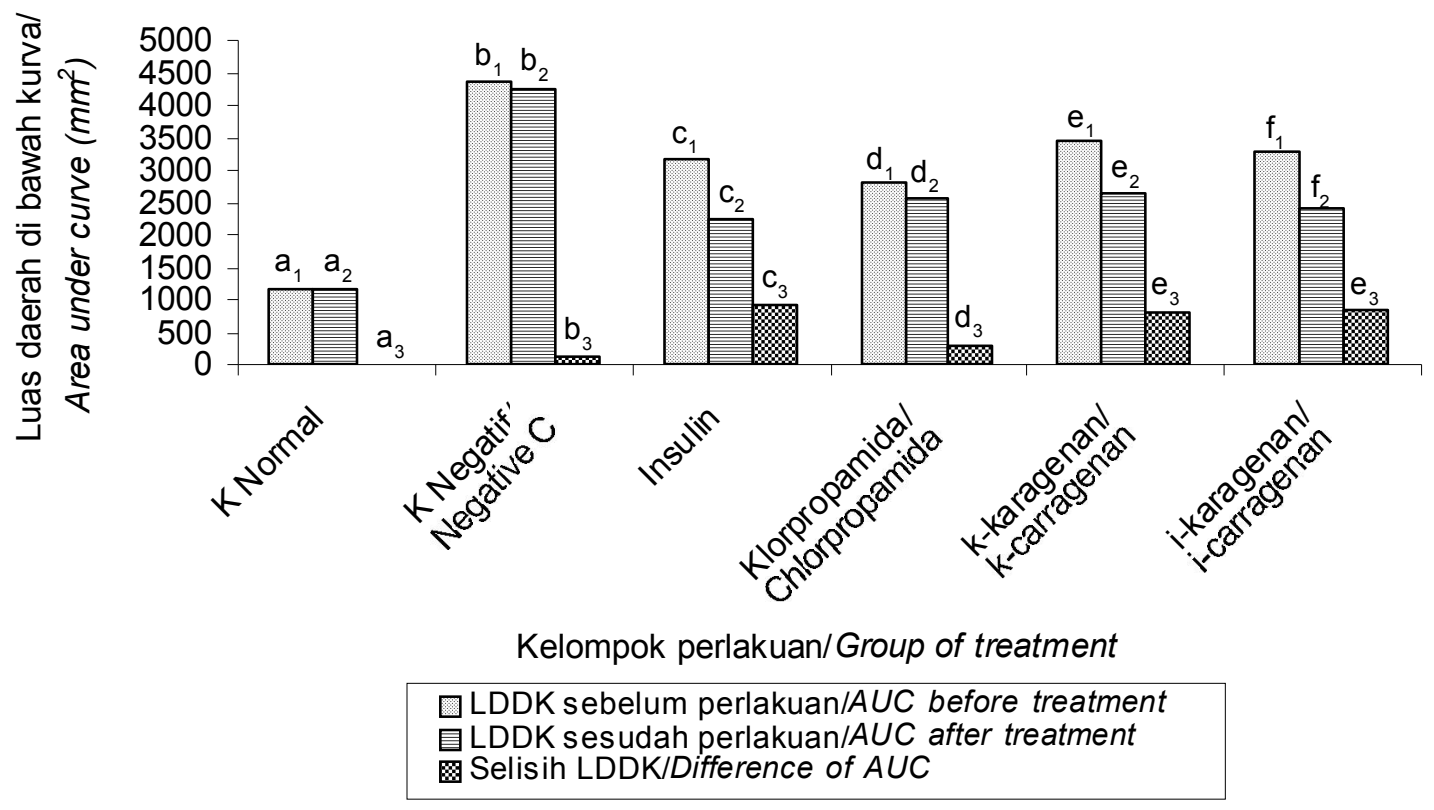

Keterangan/Note: huruf yang berbeda pada notasi yang sejenis menunjukkan berbeda nyata/the different letter on the similar natation mean significantly different.

Gambar 5. Luas daerah di bawah kurva (LDDK) kadar glukosa darah tikus sebelum dan sesudah pemberian perlakuan sediaan uji.

Figure 5. Area under curve (AUC) of rat's blood glucose level before and after treatment. 


\section{Analisis statistik luas daerah di bawah kurva (LDDK)}

Luas daerah di bawah kurva kadar glukosa darah tikus hiperglikemia sebelum dan sesudah pemberian sediaan uji, dihitung mulai dari hari ke-0, 5, 10, 15 setelah injeksi aloksan.

Perubahan kadar glukosa darah sebelum pemberian sediaan uji terlihat pada Gambar 2, dan data luas daerah di bawah kurva (LDDK) terlihat pada Gambar 5. Hasil analisis varian terhadap data yang dihasilkan menunjukkan bahwa ada perbedaan nyata antar kelompok perlakuan, maka dilanjutkan dengan uji beda nyata terkecil (BNT).

Hasil analisis luas daerah di bawah kurva (LDDK) menunjukkan bahwa pemberian injeksi insulin, klorpropamida, $\kappa$-karagenan, dan í-karagenan berbeda nyata bila dibandingkan dengan kontrol negatif. Hal ini berarti bahwa pemberian keempat perlakuan tersebut dapat menurunkan kadar glukosa darah tikus yang tinggi karena tikus mengalami kerusakan pada sel- $\beta$ pankreas akibat induksi aloksan. Dapat dinyatakan bahwa klorpropamida, $\kappa$-karagenan, dan i-karagenan dapat membantu proses perbaikan kerusakan pankreas tikus akibat induksi aloksan, sedangkan perbedaan yang nyata antara injeksi insulin dengan kontrol negatif adalah karena kemampuan atau efek insulin yang jelas berperan menurunkan kadar glukosa darah tikus.

Hasil analisis luas daerah di bawah kurva (LDDK) kadar glukosa darah sesudah pemberian sediaan uji menunjukkan bahwa $\kappa$-karagenan dan í-karagenan memberikan efek berbeda dalam menurunkan kadar glukosa darah tikus. Hal ini diduga karena ada perbedaan dalam struktur dan komposisi kimia karagenan. Senyawa í-karagenan pada suhu kamar memiliki kemampuan membentuk gel lebih lama, larut dalam air dingin dan membentuk larutan yang bersifat jauh lebih kental dibanding dengan $\kappa$-karagenan. Akibat perbedaan sifat fisika tersebut, maka dengan volume pemberian yang sama dapat menghasilkan perbedaan kekentalan cairan dalam saluran cerna, selanjutnya akan menimbulkan perbedaan kekuatan pengikatan glukosa oleh cairan saluran cerna, dan akhirnya mengakibatkan terjadinya perbedaan laju absorbsi glukosa dari saluran cerna ke dalam pembuluh darah. Hal ini mengakibatkan laju peningkatan kadar glukosa darah menjadi sangat berbeda. Kemungkinan mekanisme yang lain adalah zat-zat toksik yang ada dalam $\kappa$-karagenan turut mempengaruhi efektivitas dari $\kappa$-karagenan. Berdasarkan teori bahwa jika sel mengalami pengaruh berbahaya yang cukup hebat atau berlangsung cukup lama, maka sel akan mencapai titik atau keadaan tidak dapat mengkompensasi dan melangsungkan metabolismenya (Widowati, 2003).

Ditinjau dari selisih luas daerah di bawah kurva ternyata antara k-karagenan dan í-karagenan tidak ada perbedaan dalam kemampuan menurunkan kadar glukosa darah. Hal ini diduga karena $\kappa-k a r a g e n a n ~ d a n$ i-karagenan memiliki stabilitas yang sama pada suasana $\mathrm{pH}$ asam maupun basa di dalam saluran cerna, misalnya: sama-sama berikatan kuat dengan protein, memiliki kemampuan untuk membentuk garam dengan ion-ion tertentu, seperti ion $\mathrm{Ca}, \mathrm{K}, \mathrm{Na}$.

\section{Persentase penurunan kadar glukosa darah tikus}

Hasil perhitungan besarnya kemampuan menurunkan kadar glukosa darah tikus dari setiap

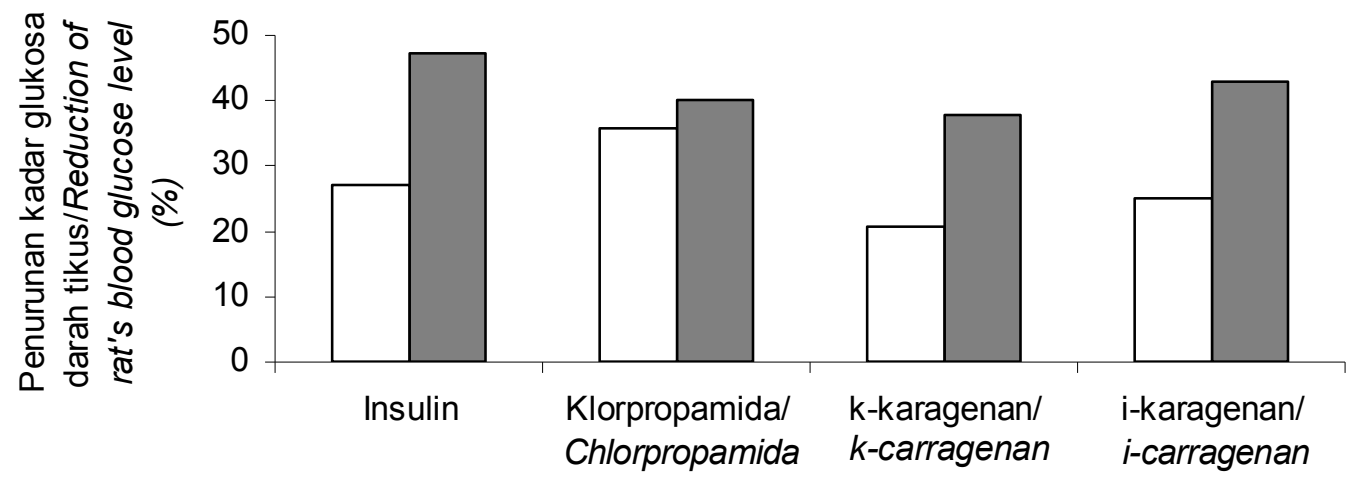

Kelompok perlakuan/Group of treatment

$\square$ Sebelum perlakuan/Before treatment

$\square$ Sesudah perlakuan/After treatment

Gambar 6. Persentase penurunan kadar glukosa darah tikus dari setiap perlakuan pada hari ke-15.

Figure 6. Reduction percentage of rat's blood glucose level of each treatment on the day-15. 
perlakuan sediaan uji dapat dilihat pada Gambar 6 . Terlihat bahwa i-karagenan memiliki kemampuan menurunkan kadar glukosa darah tikus hampir sama dengan kemampuan insulin, dan lebih baik daripada klorpropamida dan k-karagenan.

Pada saat dilakukan pembedahan, pengamatan secara makroskopik terhadap usus tikus yang diberi karagenan menunjukkan warna yang berbeda dengan tikus yang diberi sediaan uji yang lain, yaitu timbulnya warna kehitaman pada usus tikus. Hal ini mengindikasikan timbulnya kerusakan pada usus tikus yang diberi karagenan karena berdasarkan hasil beberapa penelitian, pemberian karagenan dapat menyebabkan luka pada usus, kanker usus maupun kanker lainnya pada manusia yang mengkonsumsi karagenan (Anon., 2003a; Anon., 2003b). Hidrolisis karagenan oleh enzim pencernaan dan kerja bakteri saluran cerna (yang memproduksi enzim karagenase) menghasilkan campuran senyawa polisakarida dengan bobot molekul yang kecil dan poligenan. Diduga senyawa-senyawa tersebut berbahaya yang dapat menimbulkan luka atau lesi pada saluran cerna (usus).

\section{KESIMPULAN}

1. Karagenan baik digunakan untuk menurunkan kadar glukosa darah tikus yang mengalami kerusakan pankreas akibat induksi aloksan. Pemberian $\kappa$-karagenan dapat menurunkan kadar glukosa darah tikus sebesar $37,55 \%$ dan pemberian í-karagenan dapat menurunkan kadar glukosa darah sebesar $42,87 \%$.

2. Pemberian karagenan yang salah atau berlebihan berpotensi menimbulkan dampak berbahaya pada saluran cerna, yaitu luka dan bahkan kemungkinan menimbulkan tumor.

\section{SARAN}

1. Pemakaian karagenan untuk pangan agar menggunakan dosis rendah sesuai fungsinya untuk pengental atau meningkatkan konsistensi sediaan.

2. Untuk mengeliminasi dampak negatif yang mungkin timbul pada pemakaian karagenan sebagai serat yang larut dalam air dan mengandung gugus sulfat maka perlu dipadu atau dicampur dengan jenis serat lain yang dapat mengikat air tetapi tidak larut dalam air, seperti hemiselulosa, atau derivat selulosa, dan lain-lain. sehingga dapat mencegah atau memperkecil efek iritasi dari gugusan sulfat terhadap mukosa saluran cerna.

\section{DAFTAR PUSTAKA}

Anonim. 2000. Indonesia Menduduki Peringkat ke-6 Penderita Diabetes di Asia. Kompas, Rabu 23 Agustus 2000. 10 pp, kolom 3-4.
Anonymous. 2003a. Stomach aches caused by c a rrageenan.http:/www. notmilk.com/ carrageenan.htm. Diakses tanggal 20 September 2003.

Anonymous. 2003b. Carrageenan may caused stomach aches lesions, cancer. http:/www.ENN.com/ cncer.htm. Diakses tanggal 20 September 2003.

Atmaja, W.S. 2000. Rumput laut sebagai obat. Oseana. LON-LIPI, Jakarta. 13 pp.

Dalimartha, S. 2002. Ramuan Tradisional Untuk Pengobatan Diabetes Mellitus. Penebar Swadaya, Jakarta. 28 pp .

Katzung, B.G. 1989. Farmakologi Dasar dan Klinik. Edisi 3. Alih bahasa: Binawati H.K. EGC, Jakarta. p. 577591.

KKI Phytomedica. 1993. Kelompok Kerja IImiah Phytomedica: Penapisan Farmakologi, Pengujian Fitokimia, dan Pengujian Klinik. Yayasan Pengembangan Obat Alam Phytomedica, Jakarta. p. 16-17.

Mayer, P.A. 1995. Pencernaan dan Penyerapan. Biokimia Harper. Alih bahasa: Hartono, A., EGC Penerbit Buku Kedokteran, Jakarta. 709 pp.

Reynolds, J.E.F. 1982. Martindale The Pharmacopeia. The Pharmaceutical Press, London. p. 951-952.

Ritschel, W.A, 1986. Handbook of Basic Pharmacokineties, $3^{\text {rd }}$ ed. Drug Intelligence Publications. Inc., Hamilton, USA. p. 269-281.

Sugiarto, A. 1987. Rumput Laut (Algae): Manfaat, Potensi dan Usaha Budidayanya. $\mathrm{P}_{3} \mathrm{O}$-LIPI, Jakarta. 8 pp.

Suryaningrum, T.D., Murtini, J.T., dan Erlina, M.D. 1991. Sifat Fisiko-kimia Karagenan dan Beberapa Lokasi Budidaya Rumput Laut di Indonesia. Sub Balai Penelitian Perikanan Laut Slipi. p. 75-76.

Tjokroprawiro, A. 1999. Diabetes Mellitus, Klasifikasi, Diagnosis dan Terapi. Edisi 3. Gramedia, Jakarta. p. $1-16$.

Widowati, L. 2003. Pengaruh Ekstrak Biji Trigonella Foenum-graecum L. Terhadap Kadar Gula Darah, Glutation dan Gambaran Kerusakan Sel-b Pankreas pada Tikus NIDDM. F-MIPA Universitas Indonesia, Prog Studi Kefarmasian. p. 20-21, 66-73.

Wikanta, T., Riyadi, A., dan Rahayu, L. 2000. Pengaruh pemberian natrium alginat terhadap penurunan kadar glukosa darah kelinci dengan metoda toleransi glukosa oral. Octopus. 4(1): 1-13.

Wikanta, T., Khaeroni, dan Rahayu, L. 2002. Pengaruh pemberian natrium alginat terhadap penurunan kadar glukosa darah tikus. J. Penel. Perik. Indonesia. 8(6): 21-32.

Wikanta, T., Nasution, R.R., dan Rahayu, L., 2003. Pengaruh pemberian natrium alginat terhadap penurunan kadar kolesterol total darah dan bobot badan tikus. J. Penel. Perik. Indonesia. 9(5): 23-31.

Wikanta, T., Kurniawan, R., dan Rahayu, L. 2005. Pengaruh Pemberian i-karagenan dan k- karagenan terhadap penurunan kadar glukosa darah dan histopatologi usus kelinci. J. Penel. Perik. Indonesia II(8):57-68. 